\title{
Article \\ Antibacterial Peptides Produced by Alcalase from Cowpea Seed Proteins
}

\author{
Ali Osman ${ }^{1}$, Gamal Enan ${ }^{2, *}{ }^{\mathbb{C}}$, Abdul-Raouf Al-Mohammadi ${ }^{3}$, Seham Abdel-Shafi ${ }^{2}{ }^{\mathbb{D}}$, Samar Abdel-Hameid ${ }^{2}$, \\ Mahmoud Z. Sitohy ${ }^{1}\left(\mathbb{D}\right.$ and Nashwa El-Gazzar ${ }^{2}$ (I)
}

check for

updates

Citation: Osman, A.; Enan, G.; Al-Mohammadi, A.-R.; Abdel-Shafi, S.; Abdel-Hameid, S.; Sitohy, M.Z.; El-Gazzar, N. Antibacterial Peptides Produced by Alcalase from Cowpea Seed Proteins. Antibiotics 2021, 10, 870. https://doi.org/10.3390/ antibiotics 10070870

Academic Editors:

Malgorzata Paduszynska and Jean-Marc Sabatier

Received: 8 June 2021

Accepted: 15 July 2021

Published: 17 July 2021

Publisher's Note: MDPI stays neutral with regard to jurisdictional claims in published maps and institutional affiliations.

Copyright: (c) 2021 by the authors. Licensee MDPI, Basel, Switzerland. This article is an open access article distributed under the terms and conditions of the Creative Commons Attribution (CC BY) license (https:/ / creativecommons.org/licenses/by/ $4.0 /)$.
1 Biochemistry Department, Faculty of Agriculture, Zagazig University, Zagazig 44511, Egypt; aokhalil@zu.edu.eg (A.O.); mzsitohy@hotmail.com (M.Z.S.)

2 Botany and Microbiology Department, Faculty of Science, Zagazig University, Zagazig44519, Egypt; hegazyseham@yahoo.com (S.A.-S.); dr.samar19891989@gmail.com (S.A.-H.); mora_sola1212@yahoo.com (N.E.-G.)

3 Department of Science, King Khalid Military Academy, Riyadh 11495, Saudi Arabia; almohammadi26@hotmail.com

* Correspondence: gamalenan@ymail.com

\begin{abstract}
Cowpea seed protein hydrolysates $(\mathrm{CPH})$ were output from cowpea seeds applying alcalase ${ }^{\circledR}$ from Bacillus licheniformis. CPH with an elevated level of hydrolysis was fractionated by size exclusion chromatography (SEC). Both CPH and SEC-portions showed to contain antimicrobial peptides (AMPs) as they inhibited both Gram-positive bacteria, such as Listeria monocytogenes LMG10470 (L. monocytogenes), Listeria innocua. LMG11387 (L. innocua), Staphylococcus aureus ATCC25923 (S.aureus), and Streptococcus pyogenes ATCC19615 (St.pyogenes), and Gram-negative bacteria, such as Klebsiella pnemoniae ATCC43816 (K. pnemoniae), Pseudomonas aeroginosa ATCC26853 (P. aeroginosa), Escherichia coli ATCC25468) (E.coli) and Salmonella typhimurium ATCC14028 (S. typhimurium).The data exhibited that both CPH and size exclusion chromatography-fraction 1 (SEC-F1) showed high antibacterial efficiency versus almost all the assessed bacteria. The MIC of the AMPs within SEC-F1 and CPHs were $(25 \mu \mathrm{g} / \mathrm{mL})$ against $P$. aeruginosa, E.coli and St. pyogenes. However, higher MICsof approximately 100-150 $\mathrm{\mu g} / \mathrm{mL}$ showed for both CPHs and SEC-F1 against both S. aureus and L. innocua; it was $50 \mu \mathrm{g} / \mathrm{mL}$ of $\mathrm{CPH}$ against S.aureus. The Electro-spray-ionization-mass-spectrometry (ESI-MS) of fraction (1) revealed 10 dipeptides with a molecular masses arranged from 184 Da to $364 \mathrm{Da}$ and one Penta peptide with a molecular mass of approximately $659 \mathrm{Da}$ inthe case of positive ions. While the negative ions showed 4 dipeptides with the molecular masses that arranged from $330 \mathrm{Da}$ to 373 Da. Transmission electron microscope (TEM) demonstrated that the SEC-F1 induced changes in the bacterial cells affected. Thus, the results suggested that the hydrolysis of cowpea seed proteins by Alcalase is an uncomplicated appliance to intensify its antibacterial efficiency.
\end{abstract}

Keywords: cowpea seed proteins; antibacterial activity; alcalase; protein hydrolysates; transmission electron microscopy; mass-spectrometry

\section{Introduction}

Nowadays, there is long-term use and misuse of conventional antibiotics and consequently, bacterial drug resistance is developed and leads to a severe health issue worldwide [1-6]. Asthe discovery of other novel antibiotics is difficult, recent perspectives are challenged to find out an innovative way to inhibit multi drug-resistant microbial variants including the use of natural peptide [7], probiotics [8], natural plant extracts either singly or in combination with antibiotics [9-11], nanoparticles [12,13], and phage therapy [14].Therefore, it is not surprising that the World Health Organization (WHO) ranked antibiotic resistance as a priority disease encouraging the development of novel antibiotics [10-13].The best choice and most promising candidates are still cationic antimicrobial peptides or proteins (AMPs) [15]. 
In a previous study, a protein extracted from the cowpea bean [15] and other legumes, such as soybeans [16-18], chickpeas [19], etc. has been reported to produce significant antimicrobial action. AMPs possess clear advantages over the classical antibiotics as they were used successfully for food preservation [9] without the emergence of multidrug resistant bacteria variants; they also showed a promising modulation of the host immune response $[2,20]$. AMPs are a novel and recent alternative to classical antibiotics that possess a wide inhibitory spectrum against both Gram-positive and Gram-negative pathogenic bacteria with little or no capacity to induce antimicrobial resistance [21]. This showed a further search for obtaining AMPs with broad antimicrobial activity.

A variety of methods have been proposed to enhance protein antibacterial efficacy, including chemical modifications, such as esterification [22-26] and enzymatic hydrolysis by different enzymes [27-30].Cowpea (Vigna unguiculata) is a major crop of legumes globally. In both human and animal diets, it serves as a main dietary protein source and its protein content makes it a good raw material for obtaining protein extracts and hydrolysates [31].Cowpea bean seed proteins range from $22 \%$ to $30 \%$ protein in a dry basis. The kind of enzyme utilized in bioactive peptide preparations defines hydrolysate properties and the peptides that can be separated [32]. In previous studies, successive enzymatic systems, such as Alcalase ${ }^{\circledR}$-Flavourzyme ${ }^{\circledR}(\mathrm{AF})$ and pepsin-pancreatin (PP), were used for the generating of hydrolysates and peptides which had useful effects on antidiabetics [31-35], antihypertension [32], hypocholesterolemia activity [36], antioxidant activity [37], and functional properties [7,38].

Biological activities depend on the structure and conformation of proteins. Proteolysis, besides decreasing themolecular weight, also increases the number of ionizablegroups and can expose hydrophobic groups, which can change physical and environmental interactions. Alcalase ${ }^{\circledR}$ enzyme extracted from Bacillus licheniformis [39]contains various proteinases with much specificity. Alcalase has been applied globally to present soluble hydrolysates of milk protein [25] and bioactive peptides extracted from fish [40]. At present, the antibacterial efficiency of $\mathrm{CPH}$ obtained by the action of alcalase has not been assayed. Therefore, the aim of the present work was to study the antibacterial activity of the obtained CPH by alcalase and fractions made by the size exclusion chromatography (SEC) technique and their action in bacterial cells using TEM studies.

\section{Results}

\subsection{Production of Both CPH and SEC-Fractions}

Cowpea protein isolate (CPI) is a good source of protein (92\% protein) to be applied as a starting substrate for enzymatic proteolysis. CPI was hydrolyzed with Alcalase (enzyme/substrate ratio 1:200) at $55^{\circ} \mathrm{C}$ and $\mathrm{pH} 7.8$ with varied proteolysis times from 60 to $240 \mathrm{~min}$. The degree of hydrolysis (DH) was estimated for the obtained hydrolysates with this treatment and the data are given in Figure 1. CPH obtained after 60, 120, 180 and 240 min showed $\mathrm{DH}$ rates of $10 \%, 15 \%, 22 \%$ and $26 \%$, respectively.

The antibacterial activity of $\mathrm{CPH}$ was estimated. $\mathrm{CPH}$ with a $\mathrm{DH}$ of approximately $26 \%$, generated by treatment with Alcalase for $240 \mathrm{~min}$, gave the highest inhibitory activity against Gram-positive and Gram-negative bacteria. This was purified by gel filtration on Sephadex G-25 to produce the bioactive fractions. As reported in Figure 2, there are two major absorbance peaks (fraction 1 and fraction 2) at $280 \mathrm{~nm}$ (Figure 2). Fractions correlated with each peak were dialyzed against distilled water for 3 days, lyophilized, and then estimated for their antibacterial activity. 


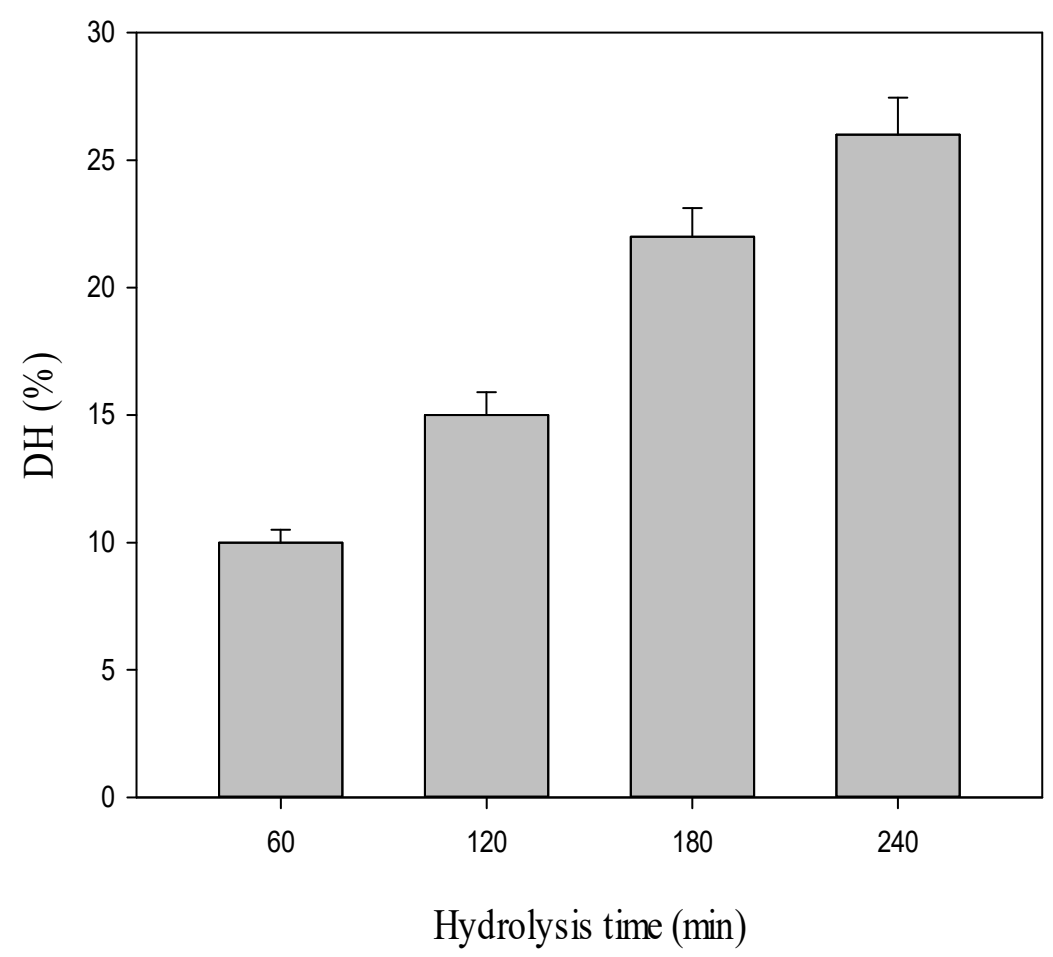

Figure 1. Degree of hydrolysis percentage ( $\mathrm{DH} \%)$ of cowpea protein hydrolysate $(\mathrm{CPH})$ obtained by treatment with Alcalase (E/substrate ratio 1:200) for $240 \mathrm{~min}$ at $55^{\circ} \mathrm{C}$ and $\mathrm{pH} 7.8$.

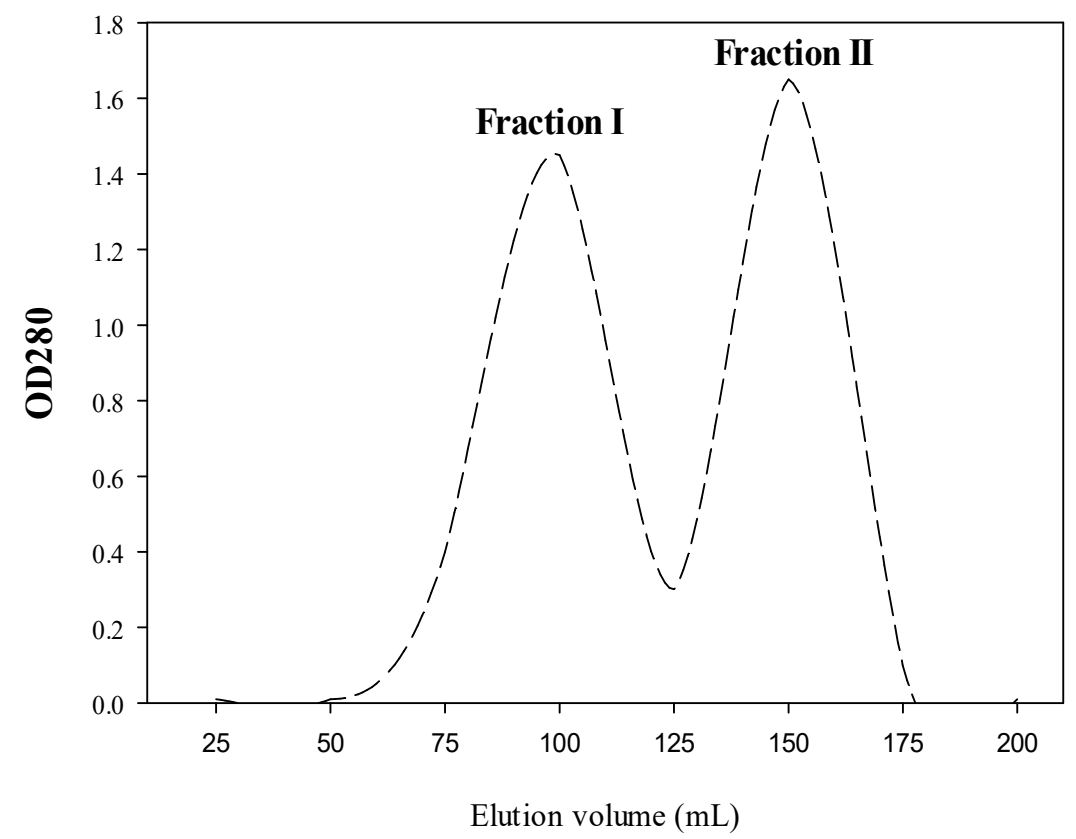

Figure 2. Size exclusion chromatography (SEC) using Sephadex G-25 of the 4 h cowpea seed protein hydrolysate $(\mathrm{CPH})$ obtained by treatment with Alcalase.

\subsection{Electro-Spray-Ionization-Mass-Spectrometry (ESI-MS) of SEC-F1}

Fraction 1 obtained from gel filtration chromatography (Figure 2) displayed the highest antibacterial activity against the tested bacteria. Therefore, the AMPs in fraction 1 were analyzed by electro-spray-ionization-MS (ESI-MS) and included both positive and negative ions for molecular weight determination; the identification of the AMPsand the main peaks are given in Figure 3. 

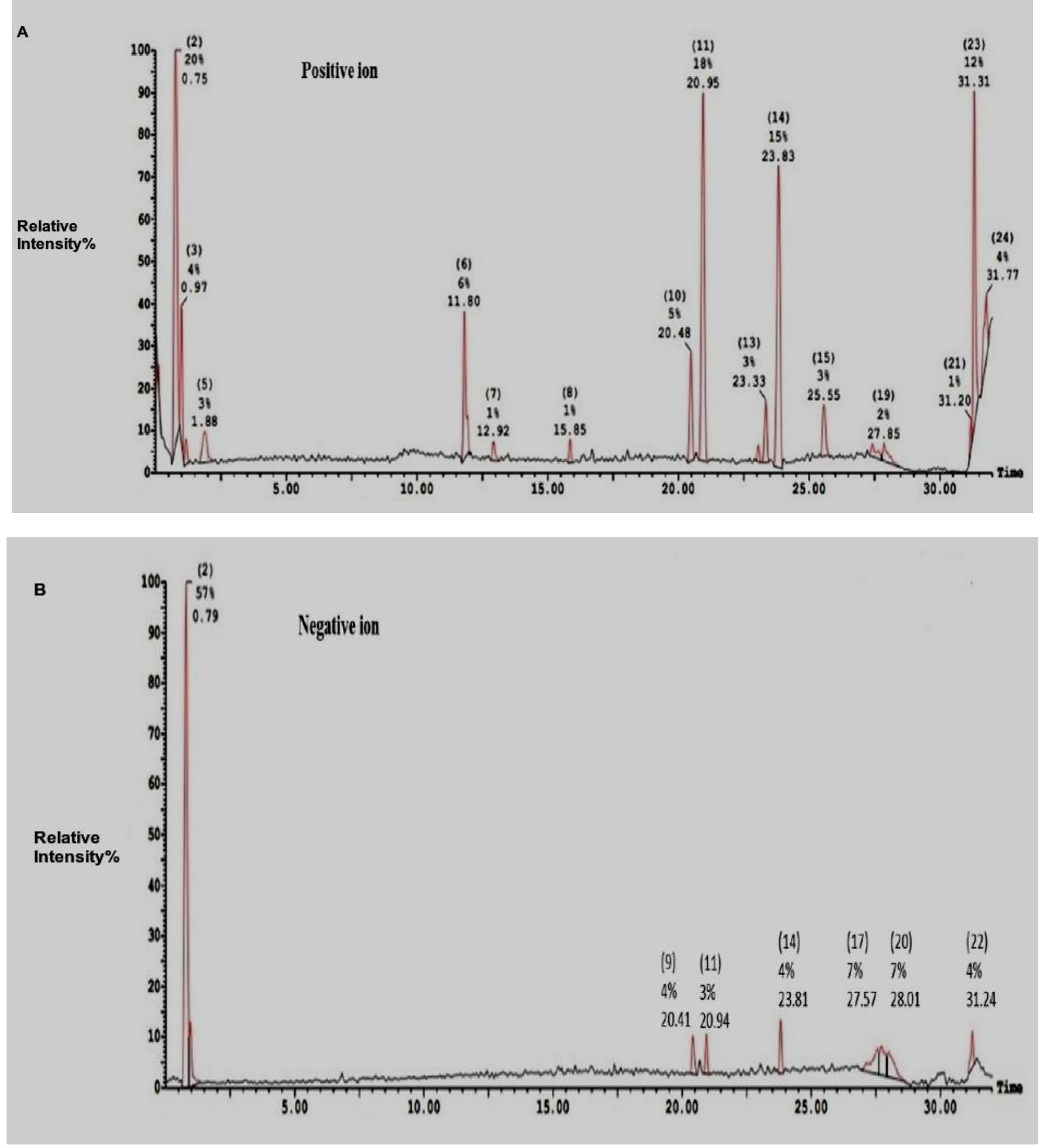

Figure 3. Chromatogram of peptides formation from size exclusion chromatography of fraction 1 showing (A): Positive ions portion and (B): Negative ions portion.

The possible peptide compositions of fraction (1) estimated by ESI-MS are given in Table 1. The AMPs within SEC-F1 were investigated by Electro-Spray-Ionization-MS. This was mandatory to assess the bioactivity of components within the AMPs. Results are given in Table 1. The positive ions fraction elucidated 9-dipeptides with molecular masses ranging from $184.94 \mathrm{Da}$ to $364 \mathrm{Da}$ and one penta-peptide containing 5 amino acid residues, such asCya am, Trp, Met and Arg. In view of the amino acid composition of the positive 
ions fraction, non-polar hydrophobic amino acids, such as glycine, alanine, valine, leucine, and tryptophan, predominated the composition of these bioactive peptides. Regarding the negative ion-fractions, peptides of molecular masses in the range $318 \mathrm{Da}$ to $373 \mathrm{Da}$ were shown and included 4-dipeptides viz. Trp-Cys am, Trp-Trp, Arg-Cys am and Phe-Trp. Also, a tetra-peptide was shown viz. Trp-Met-Arg-Cys am (Table 1). In view of the amino acids within the negative ions fraction, the majority of amino acids were hydrophobic, e.g. tryptophan (5residues), methionine (1 residue), Phenylalanine (1 residue). Three peptides out of the 10 peptides revealed in positive ions mode contained arginine, i.e. they are cationic peptides with positive charges. Likewise two peptides out of the five peptides revealed in the negative ions mode contained arginine, i.e. they are cationic peptides. Both hydrophobic and alkaline peptides are known for their antimicrobial activity [40].

Table 1. Possible peptide compositions of AMPs within size exclusion chromatography fraction 1 (SEC-F1) estimated by electro-sprayionization MS (ESI-MS) technique.

\begin{tabular}{|c|c|c|c|c|}
\hline Ions Mode/Pe & nber & Area (\%) & Molecular Weight & Composition \\
\hline \multirow{10}{*}{ Positive ions } & 2 & 20.20 & $707.32(364)$ & Cys am-Trp \\
\hline & 3 & 4.10 & $707.28(364)$ & Cys am-Trp \\
\hline & 5 & 2.57 & 192.05 & Ser-Cys \\
\hline & 6 & 6.46 & 274.20 & Trp-Ser \\
\hline & 10 & 4.57 & 331.28 & Cys-Arg \\
\hline & 11 & 18.28 & 659.43 (312 \& 318) & His-Cysam \& Trp-Met \& Arg-Cys am \\
\hline & 13 & 2.54 & 359.31 & Trp-Cys am \\
\hline & 14 & 15.29 & 359.31 & Trp-Cys am \\
\hline & 23 & 12.09 & $\begin{array}{l}184.94 \\
226.89\end{array}$ & $\begin{array}{l}\text { Leu-Ala } \\
\text { Gln-Pro }\end{array}$ \\
\hline & 24 & 3.86 & 214.06 & $\begin{array}{l}\text { Asn-Val; } \\
\text { Arg-Gly }\end{array}$ \\
\hline \multirow{5}{*}{ Negative ions } & 2 & 57.28 & 719.35 fragmented into $(365)$ & Trp-Cys am \\
\hline & 9 & 3.94 & 373 & Trp-Trp \\
\hline & 11 & 3.27 & 656.97 fragmented into (318) & Trp-Met \& Arg-Cys am \\
\hline & 17 & 7.07 & 1133.01 fragmented into $(330)$ & Arg-Cys am \\
\hline & 20 & 7.31 & 532.97 fragmented into (332) & Phe-Trp \\
\hline
\end{tabular}

\subsection{Antibacterial Activity}

The $\mathrm{CPH}(\mathrm{DH}, 26 \%)$ and its two fractions obtained by gel filtration chromatography (Figure 2) were bioassayed against Gram-positive and Gram-negative bacteria. The antibiotic ciprofloxacin was used as a positive control. The results are given in Table 2. The AMPs of both CPH and SEC-F1 showed distinctive antibacterial activity against the indicator organisms tested than that obtained by SEC-F2. This inhibitory activity of the AMPs (CPHs, SEC-F1) against the sensitive bacteria matched almost that obtained by the antibiotic ciprofloxacin $(10 \mu \mathrm{g} / \mathrm{mL})$, except for S.aureus, which showed more inhibition by the AMPs than that obtained by the antibiotic ciprofloxacin. Almost all the indicator bacteria were significantly inhibited by both $\mathrm{CPH}$ and SEC-F1.The diameters of the inhibition zones were in the range 16-26mm (Table 2). Consequently, both CPH and SEC-F1 were used for further studies. 
Table 2. Antibacterial activity of cowpea protein hydrolysate (CPH) and size exclusion chromatography (SEC) fractions (1 and 2) against tested bacteria.

\begin{tabular}{|c|c|c|c|c|c|}
\hline \multirow{2}{*}{\multicolumn{2}{|c|}{ Bacteria }} & \multicolumn{4}{|c|}{ Inhibition Zone Diameter (mm) } \\
\hline & & $\begin{array}{c}\text { Ciprofloxacin } \\
(100 \mu \mathrm{g} / \mathrm{mL})\end{array}$ & $\mathrm{CPH}$ & SEC-Fraction 1 & SEC-Fraction 2 \\
\hline \multirow{4}{*}{$G+$ VeBacteria } & St. pyogenes & $20.0 \pm 0.19$ & $24.70 \mathrm{a} \pm 0.51$ & $26.50 \mathrm{a} \pm 0.67$ & $8.50 \mathrm{~b} \pm 0.31$ \\
\hline & L. monocytogens & $23.0 \pm 0.45$ & $22.30 \mathrm{a} \pm 0.47$ & $21.50 \mathrm{~b} \pm 0.34$ & 00.00 \\
\hline & L. innocua & $22.0 \pm 0.47$ & $21.50 \mathrm{~b} \pm 0.67$ & $22.60 \mathrm{a} \pm 0.67$ & $7.60 c \pm 0.27$ \\
\hline & S. aureus & $18.0 \pm 0.22$ & $26.30 \mathrm{a} \pm 0.34$ & $23.50 b \pm 0.66$ & 00.00 \\
\hline \multirow{4}{*}{ G-VeBacteria } & S. typhimurium & $21.0 \pm 0.12$ & $24.30 \mathrm{a} \pm 0.31$ & $21.63 b \pm 0.12$ & $9.00 \mathrm{c} \pm 0.11$ \\
\hline & k. pneumonia & $18.0 \pm 0.21$ & $20.80 \mathrm{~b} \pm 0.19$ & $21.50 \mathrm{a} \pm 0.81$ & $8.300 \mathrm{c} \pm 0.17$ \\
\hline & P. auriginosa & $21.0 \pm 0.12$ & $25.30 \mathrm{a} \pm 0.12$ & $18.3 .50 \mathrm{~b} \pm 0.22$ & $9.30 c \pm 0.61$ \\
\hline & E. coli & $18.0 \pm 0.22$ & $17.3 .50 \mathrm{~b} \pm 0.57$ & $23.50 \mathrm{a} \pm 0.45$ & $8.60 c \pm 0.86$ \\
\hline
\end{tabular}

Mean in the same row having different letters are significantly different $(p \leq 0.05)$.

\subsection{Minimum Inhibitory Concentration (MIC) of Both CPHs and SEC-Fractions}

The MIC values of both CPHs and SEC-F1 were $25 \mu \mathrm{g} / \mathrm{mL}$ versus $S$. typhimurium, $K$. pneumoniae, St. pyogenes, L. monocytogenes, P. aeruginosa and E. coli (Table 3). They were of approximately $100 \mu \mathrm{g} / \mathrm{mL}$ of SEC-F1 and of approximately $150 \mu \mathrm{g} / \mathrm{mL} ; 50 \mu \mathrm{g} / \mathrm{mL}$ of CPHs against L. innocua, S. aureus, respectively (Table 3). The MIC of the control antibiotic ciprofloxacin was shown to be $20 \mu \mathrm{g} / \mathrm{mL}$.

\subsection{Transmission Electron Microscope (TEM) of SEC-F1}

The treatment of both S. typhimurium and P. aeruginosa suspensions with $25 \mu \mathrm{g} / \mathrm{mL}$ of SEC-F1 has led to an obvious increase in damaged cells after their incubation at $37^{\circ} \mathrm{C}$, as exhibited by TEM images in Figure 4. The analysis of TEM images indicate that the cationic antimicrobial proteins cause overall deterioration of cell membranes, cell swelling, vacuoles composition and finally whole lysis of cell components.

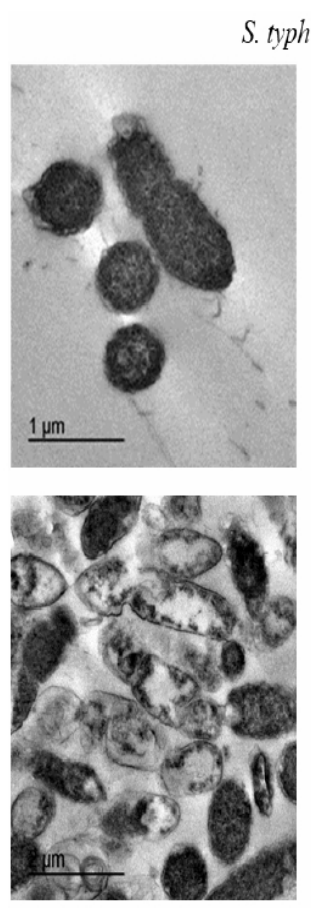

$50,000 x$ typhimurium
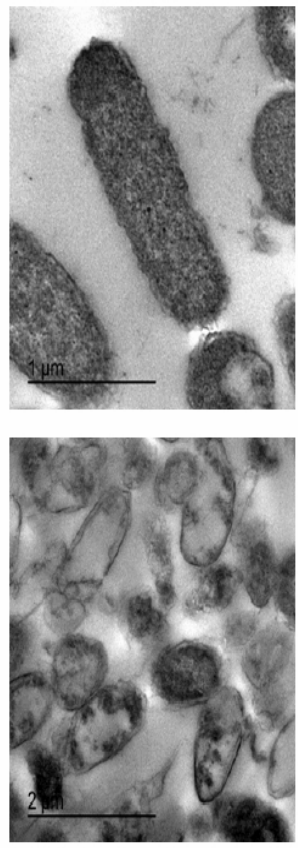

$60,000 x$

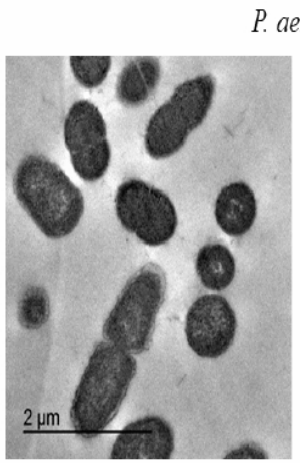

P. aeruginosa
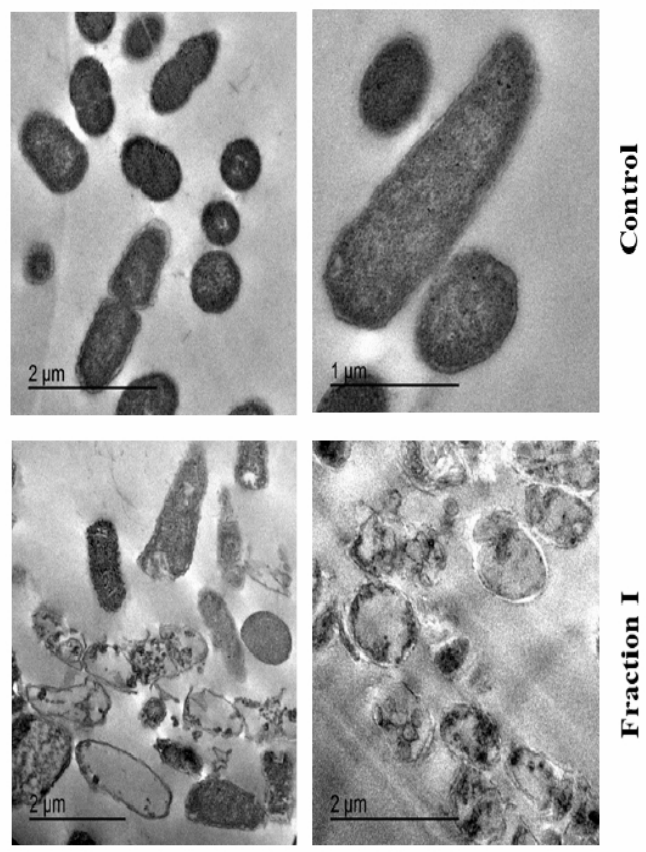

$50,000 x$

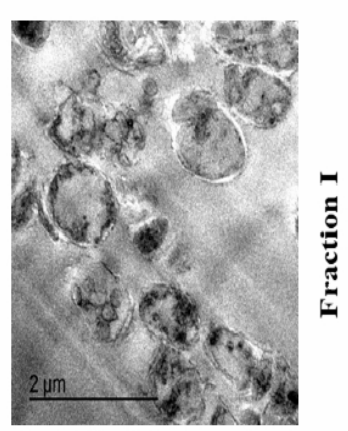

$60,000 x$

Figure 4. Transmission electron microscope (TEM) of control and treated bacteria (S. typhimurium and $P$. aeruginosa) as affected by $25 \mu \mathrm{g} / \mathrm{mL}$ of size exclusion chromatography fraction number 1 . 
Table 3. Minimum inhibitory concentration (MIC) of CPH and (SEC-F1) against tested bacteria.

\begin{tabular}{|c|c|c|c|c|c|c|c|c|c|c|c|c|}
\hline \multirow{3}{*}{ Microorganisms } & \multicolumn{12}{|c|}{ Inhibition Zone Diameter $\left(\mathrm{mm} / \mathrm{\mu g} \mathrm{mL}^{-1}\right)$} \\
\hline & \multicolumn{2}{|c|}{25} & \multicolumn{2}{|c|}{50} & \multicolumn{2}{|c|}{100} & \multicolumn{2}{|c|}{250} & \multicolumn{2}{|c|}{500} & \multicolumn{2}{|c|}{1000} \\
\hline & $\mathrm{CPH}$ & $F_{1}$ & $\mathrm{CPH}$ & $F_{1}$ & $\mathrm{CPH}$ & $F_{1}$ & $\mathrm{CPH}$ & $F_{1}$ & $\mathrm{CPH}$ & $F_{1}$ & $\mathrm{CPH}$ & $F_{1}$ \\
\hline S. typhimurum & $11.0 \mathrm{~d} \pm 0.3$ & $15.0 c \pm 0.1$ & $17.0 \mathrm{~b} \pm 0.3$ & $18.0 \mathrm{~b} \pm 0.5$ & $18.0 \mathrm{~b} \pm 0.1$ & $18.6 \mathrm{~b} \pm 0.4$ & $21.0 \mathrm{~b} \pm 0.5$ & $22.0 \mathrm{~b} \pm 0.1$ & $21.0 c \pm 0.7$ & $29.0 \mathrm{a} \pm 0.6$ & $22.0 \mathrm{~d} \pm 0.5$ & $29.6 \mathrm{a} \pm 0.5$ \\
\hline К. рпеитопіае & $15.6 b \pm 0.3$ & $12.0 \mathrm{~d} \pm 0.1$ & $15.7 \mathrm{c} \pm 0.8$ & $12.7 \mathrm{c} \pm 0.2$ & $16.0 c \pm 0.3$ & $14.0 \mathrm{c} \pm 0.7$ & $20.0 \mathrm{~b} \pm 0.6$ & $15.0 \mathrm{~d} \pm 0.9$ & $21.0 c \pm 0.4$ & $18.0 \mathrm{~d} \pm 0.2$ & $24.0 \mathrm{c} \pm 0.4$ & $2.02 c \pm 0.3$ \\
\hline St. pyogenes & $13.0 \mathrm{c} \pm 0.7$ & $24.0 \mathrm{a} \pm 0.4$ & $17.9 b \pm 0.8$ & $26.0 \mathrm{a} \pm 0.7$ & $20.0 \mathrm{a} \pm 0.7$ & $28.0 \mathrm{a} \pm 0.1$ & $24.0 \mathrm{a} \pm 0.2$ & $18.0 \mathrm{c} \pm 0.3$ & $26.0 \mathrm{~b} \pm 0.1$ & $20.0 c \pm 0.2$ & $28.3 b \pm 0.3$ & $27.0 \mathrm{~b} \pm 0.4$ \\
\hline L.monocytogen & $9.0 \mathrm{e} \pm 0.1$ & $9.0 \mathrm{e} \pm 0.3$ & $9.5 \mathrm{~d} \pm 0.2$ & $10.3 \mathrm{~d} \pm 0.3$ & $10.0 \mathrm{~d} \pm 0.8$ & $13.0 c \pm 0.8$ & $23.0 \mathrm{ab} \pm 0.1$ & $15.3 \mathrm{~d} \pm 0.4$ & $18.3 d \pm 02$ & $25.0 \mathrm{~b} \pm 0.1$ & $19.6 \mathrm{e} \pm 0.8$ & $20.3 \mathrm{~d} \pm 0.1$ \\
\hline L. innосиа & 0.0 & 0.0 & 0.0 & 0.0 & 0 & $11.3 \mathrm{~d} \pm 0.2$ & $14.0 \mathrm{c} \pm 0.5$ & $12.7 \pm 0.3$ & $20.3 c \pm 0.4$ & $13.3 f \pm 0.5$ & $22.0 \mathrm{~d} \pm 0.2$ & $22.0 c \pm 0.1$ \\
\hline P. aeruginosa & $18.0 \mathrm{a} \pm 0.5$ & $18.0 \mathrm{~b} \pm 0.3$ & $19.0 \mathrm{a} \pm 0.4$ & $19.0 \mathrm{~b} \pm 0.2$ & $19.3 a \pm 0.5$ & $19.3 b \pm 0.4$ & $23.0 \mathrm{ab} \pm 0.6$ & $23.0 b \pm 0.9$ & $20.00 c \pm 3$ & $20.0 c \pm 0.2$ & $20.0 \mathrm{e} \pm 0.5$ & $16.7 \mathrm{e} \pm 0.2$ \\
\hline E. coli & $15.0 \mathrm{~b} \pm 0.15$ & $24.0 \mathrm{a} \pm 0.3$ & $20.6 \mathrm{a} \pm 0.3$ & $25.7 \mathrm{a} \pm 0.1$ & $19.3 \mathrm{a} \pm 0.1$ & $27.0 \mathrm{a} \pm 0.5$ & $26.0 \mathrm{a} \pm 0.4$ & $29.0 \mathrm{a} \pm 0.1$ & $30.0 \mathrm{a} \pm 0.4$ & $31.0 \mathrm{a} \pm 0.4$ & $32.0 \mathrm{a} \pm 0.7$ & $31.3 \mathrm{a} \pm 0.3$ \\
\hline
\end{tabular}

Mean in the same row having different letters are significantly different $(p \leq 0.05)$. 


\section{Discussion}

The high incidence of resistant bacteria variants to antibiotics has a vast impact on human mortality and healthcare $[5,15,35]$. Many bacteria have become resistant against many antimicrobial agents. Thus, there is an urgent demand to find other alternative antimicrobial agents which could kill the multidrug-resistant bacteria [15]. AMPs are highly active against most microbes, including both Gram-positive and Gram-negative bacteria [40].

AMPs are promising new antibacterial agents due to their killing mechanism via interaction with bacterial cell walls and membranes [19,41].They could be generated by different methods, such as chemical modification [23], microbial fermentation [42] and enzymatic proteolysis [29]. Alcalase has been used to generate biologically active peptides from different sources, such as barbel muscle protein [40], goat whey protein [27], sorghum protein [43], chickpea protein [44], canola protein [45], and egg [46],that cleaves the high molecular weight, releasing more active subunits with smaller molecular sizesand with a hydrophobic nature that showed greater antimicrobial activity [41]. This optimization produces effective bactericidal peptides that may be identified as potential antimicrobials $[41,47,48]$.

Protein substrates play an important role in the biological activities of protein hydrolysates. In the current research, ocwpea protein isolate was used as a starting substrate for hydrolysis with Alcalase. A similar tendency of DH was determined from the hydrolysis of soy protein with Alcalase. [49]. The degree of hydrolysis was recorded for the obtained hydrolysates at different times, similar to that reported by Osman et al. [27]. The form of the hydrolysis curve in the present work is typical of those already published by Osman et al. [27]. It was reported from the previous studies that high DH by Alcalase is necessary for the most active protein solubility, emulsifying efficiency and adequate functionality. The solubility of cowpea protein hydrolysate was adequately optimized by response surface techniques, and the hydrolysate recorded a potent functionality [50].

The antibacterial activity of $\mathrm{CPH}$ at different times (60-240 $\mathrm{min}$ ) was estimated. $\mathrm{CPH}$, with a $\mathrm{DH}$ of $26 \%$ generated by treatment with Alcalase for $240 \mathrm{~min}$ presented the highest action against Gram-positive and Gram-negative bacteria. This antibacterial efficiency showed greater inhibitory zones against almost all the tested bacteria. This is probably due to the liberation of some antibacterial peptides upon Alcalase hydrolysis of the cowpea seed proteins [28]. The interaction of antimicrobial peptides with bacterial cells is dependent on their amino acid composition and their methyl groups that process cationic charges which could connect to cell membrane bilayers, and in turn cause pore formation [41]. This mechanism might happen through electrostatic binding between the positively charged parts of the cationic proteins and the negatively charged layers of the cell membrane rising from teichoic acid and phospholipid components causing cell degeneration, and in turn cell lysis or destructionleading to leakage of cell electrolytes [51].

Due to the high antibacterial activity of $\mathrm{CPH}$, it was purified by gel filtration onSephadex G-25 to produce the bioactive fractions. Concerning the bioactive components within the investigated AMPs, the positive ions portion include non-polar hydrophobic amino acids in 9 out of 11 residues investigated, such as Cys am-Trp, Cys am-Trp, Trp-Ser, His-Cys am, Trp-Met-Arg (penta-peptide), Trp-Cys am (2 residues), Leu-Ala, Asn-Val and Arg-Gly, which were known to attach the negatively charged phospholipid of bacterial cell membranes; making electrostatic forces which could make pores within bacterial cell membranes; from which cell electrolytes can emerges outside bacterial cells [15,22]. Also, the residues containing Sulphur, such as met within the pentapeptide and cysteine showed to be of distinctive antimicrobial activity [52]. The bioactive components within the amino acids of the negative ions portion contained tryptophane within 4 residues out of 5 residues detected and showed to be bioactive components, as shown above, for the positive ions of fraction [41]. Moreover, the releasing of peptides with a smaller molecular mass by alcalase is of more mobility and inhibitory activity than the ones with high molecular weight [53]. In addition, the Arg-Cys am residue showed previouslya distinctive bioactivity against bac- 
teria since the amino group of arginine could accept the proton-giving, positively-charged $\mathrm{NH}^{+}$group, which could attach with the negatively- charged bacterial cell membrane, giving bacterial death [52].

The recent perspectives are to use the AMPs in mixtures as these mixtures showed greater antimicrobial activity. Pfalzgraff et al. [54] discussed the antimicrobial activity of some AMPs and their therapeutic potential for skin infections and wounds. The AMPs in a mixed peptide showed promising use as a surface therapy and inhibited skin infections caused by Enterococcus faecium, Staphylococcus aureus, Pseudomonas aeruginosa, Klebsiella pneumonia and Acenetobacter baumanni.

The effects of SEC-F1 peptides that appeared herein showed several signs of cellular deformation as shown by TEM- studies, reflecting a direct disruptive influence of this fraction on the cell wall and cell membrane. Distorted cells pointed to cell shrinkage, cell membrane wrinkles, and pore formation, and also some emptiness of cellular live material [45]. These results are in confirmation with the previous reports of the direct interaction of cationic antimicrobial peptides with the cell membranes and follow previously published works [41,48].

Thus, the results provide critical information on $\mathrm{CPH}$ that may be used as active ingredients to formulate antibacterial peptides. Further work will be necessary to improve the inhibitory activity of AMPs by their chemical modification via their methylation, and to investigate the antimicrobial activity of such peptides in foods. The antimicrobial activity of these peptides in combination with antibiotics is also necessary. Work in this respect is in progress.

\section{Materials and Methods}

\subsection{Collection of Pathogenic Bacteria}

Both Gram-positive bacteria, such as L. monocytogenes, L. innocua, S. aureus, and St. pyogenes, and Gram-negative bacteria, such as K. pnemoniae, P. aeroginosa, E. coli and S. typhimurium were used. All the bacteria were stored as stock cultures in glass beads at $-20^{\circ} \mathrm{C}$, subcultured and propagated in a brain heart infusion broth (Oxoid). Prior to the microbiological work, slope cultures were grown onto the brain heart infusion broth (Oxoid) as described previously by Abdel-Shafi et al., 2019 [15] and stored at $4^{\circ} \mathrm{C}$ during experiments.

\subsection{Plant Materials and Chemicals}

The cowpea (Vigna unguiculata, L.) seeds were provided from local market, Zagazig, Sharkia Governorate, Egypt. These seeds were identified by Dr. Samir Salem, Botany, Dept. Fa of Sci., Za. Univ, Egypt. Alcalase enzyme is a product metabolite from B. licheniformis; it was purchased from Sigma (St. Louis, MO, USA).

\subsection{Cowpea Protein Isolation}

Cowpea seeds $(1 \mathrm{~kg})$ were ground and $\mathrm{n}$-hexane $(5 \% \mathrm{w} / \mathrm{v})$ was used for $8 \mathrm{~h}$ to produce flour. On a rotary evaporator, the solvent was evaporated and the dried-defatted meal was deposited at $4^{\circ} \mathrm{C}$ before analysis was performed. The total protein was isolated from the defatted flour by precipitation with $0.1 \mathrm{~N} \mathrm{HCl}$ at $\mathrm{pH} 4.5$ using the procedures previously mentioned [16,22], dialyzed against distilled water for 4 days, lyophilized, and stored at $-20^{\circ} \mathrm{C}$ until used.

\subsection{Cowpea Seed Protein Hydrolysates Preparation}

The CPHs were prepared as described by Otte et al. [55]. In $100 \mathrm{~mL}$ of distilled water, lyophilized cowpea protein isolate $(10 \mathrm{~g})$ was dissolved and the $\mathrm{pH}$ was adjusted to 7.8 . In order to achieve a final enzyme/substrate (E/S) ratio of 1:200, Alcalase was added. The reaction was permitted to continue for $240 \mathrm{~min}$ under continuous stirring at $55^{\circ} \mathrm{C}$, with the $\mathrm{pH}$ held at 7.8. The reaction was prevented by heating for $10 \mathrm{~min}$ at $100^{\circ} \mathrm{C}$ and then cooling at $4{ }^{\circ} \mathrm{C}$ in an ice bath. The collected protein hydrolysates were freeze-dried and stored 
at $-4^{\circ} \mathrm{C}$. The degree of hydrolysis $(\mathrm{DH})$ was calculated every $60 \mathrm{~min}$ during hydrolysis according to Adler-Nissen [56]. The hydrolysate was clarified by centrifugation at $4000 \times$ $g$ for $30 \mathrm{~min}$ at $16^{\circ} \mathrm{C}$ to remove insoluble substrate fragments, and the supernatant was lyophilized and kept frozen at $-20^{\circ} \mathrm{C}$ until used. The antibacterial activity of the $\mathrm{CPH}$ was tested against the pathogenic bacteria used and the highest antibacterial agent was separated by sizeexclusion chromatography (SEC).

\subsection{Fractionation of CPH by Size Exclusion Chromatography (SEC)}

The CPH obtained after 240 min of hydrolysis time with Alcalase, with the highest antibacterial activity and $26 \%$ degree of hydrolysis was fractionated by SEC using a Sephadex G-25 gel filtration column $(1.6 \times 150 \mathrm{~cm})$. After dissolving the $\mathrm{CPH}$ in deionized water, $10 \mathrm{~mL}$ of the $\mathrm{CPH}$ solution were added to the column and eluted with distilled water at a flow rate of $1 \mathrm{~mL} / \mathrm{min}$, and the $\mathrm{OD}$ was measured at $280 \mathrm{~nm}$. The main peaks were collected and lyophilized to evaluate their antibacterial efficiency.

\subsection{Electro-Spray-Ionization-Mass-Spectrometry (ESI-MS) of SEC-F1}

The main peak (SEC-F1) with the highest antibacterial activity was subjected to electrospray-ionization-mass-spectrometry (ESI-MS) positive and negative ion. An aliquot of approximately $10 \mu \mathrm{l}$ of the final peptide solution was injected into the chromatograph and the peptides were separated on a XEVO TQD triple quadruple instrument Water Corporation, Milford, MA01757 U.S.A, mass spectrometer. Column: ACQUITY UPLC-BEH C18 $1.7 \mu \mathrm{m}-2.1 \times 50 \mathrm{~mm}$ Column with flow rate: $0.2 \mathrm{~mL} \backslash \mathrm{min}$ using solvent system: consisted of (A) Water containing $0.1 \%$ formic acid (B) Acetonitrile containing $0.1 \%$ formic acid [41].

\subsection{Antibacterial Activityof CPH and Fractions Obtained by SEC}

Both CPH and SEC fractions (F1 and F2) were bio assayed against Gram-positive bacteria, such as L. monocytogenes, L. innocua, S. aureus and St. pyogenes, and Gram-negative bacteria, such as K. pneumonia, P. aeruginosa, E. coli and S. typhimurium by the Kirby-Bauer disk-diffusion method [57]. The indicator bacteria were swabbed onto the surface of brain heart infusion agar (Oxoid) plates. Then, filter paper discs were soaked in either $\mathrm{CPH}$ or SEC fractions for $15 \mathrm{~min}$ and put onto the agar plates that were previously seeded with the indicator bacteria. After incubation for $24 \mathrm{~h}$, diameters of inhibition zones were measured by anmm ruler after subtracting the diameter of the filter paper disc $[48,57,58]$.

\subsection{Minimum Inhibitory Concentration (MIC) Determination of Both CPH and SEC-F1}

MIC values of both CPH and SEC-F1 were tested against both Gram-positive bacteria (L. monocytogenes, L. innocua, S. aureus and St. pyogenes) and Gram-negative bacteria (K. pneumoniae, P. aeruginosa, E. coli and S. typhi) by the Kirby-Bauer disk-diffusion method. The bacterial suspension was swabbed onto the surface of the brain heart infusion agar (Oxoid) plates. Then filter paper disks of $6 \mathrm{~mm}$ in diameter were soaked in either $\mathrm{CPH}$ or SEC F1 $(25,50,100,250,500,1000 \mu \mathrm{g} / \mathrm{mL})$ and placed onto an agar surface with suitable distances separating them from each other. The plates were incubated at $37^{\circ} \mathrm{C}$ for $24 \mathrm{~h}$ and inhibition zone diameters $(\mathrm{mm})$ were measured through a millimeter ruler [59].

\subsection{Transmission Electron Microscope (TEM) of SEC-F1}

Since, both S. typhimurium and P. aeruginosa were highly inhibited by either $\mathrm{CPH}$ or SEC-F1 AMPs, they were selected for TEM studies. They were also chosen as the authors investigating the action of these peptides in later work [15]. S. typhi and P. aeruginosa were selected for TEM. The bacteria were grown in a brain heart infusion broth and incubated at $37^{\circ} \mathrm{C}$ to record a growth of approximately $10^{9} \mathrm{CFU} / \mathrm{mL}$, which was consequently diluted to the desired CFU mL ${ }^{-1}$. The MICs aliquots ( $25 \mu \mathrm{gmL}^{-1}$ of SEC-F1) were added to both the $S$. typhi and P. aeruginosa cell suspensions, respectively, except control, and incubated at $37^{\circ} \mathrm{C}$ for $4 \mathrm{~h}$. Ultrathin sections were prepared for study by TEM. Perfusion 
or immersion fixation of the bacteria was determined through the method adopted by Morris [60]. The cells were kept overnight at $4^{\circ} \mathrm{C}$, then washed 3 times for $15 \mathrm{~min}$ in a $0.1 \mathrm{M}$ sodium phosphate buffer $+0.1 \mathrm{M}$ sucrose and post fixed 90 min using a $2 \%$ Na phosphate buffered osmium tetroxide ( $\mathrm{pH}$ 7.4). They were then washed $3 \times$ for $15 \mathrm{~min}$ in a $0.1 \mathrm{M}$ sodium phosphate buffer $\mathrm{pH} 7.4$ and dehydrated $2 \times$ for $15 \mathrm{~min}$ : 50\% ethanol (in distilled water). They were then contrasted overnight using $70 \%$ acetone $+0.5 \%$ uranyl acetate $+1 \%$ phosphor tungstic acid at $4^{\circ} \mathrm{C}, 2 \times$ for $15 \mathrm{~min}, 80 \%$ ethanol, $2 \times$ for $15 \mathrm{~min}, 90 \%$ ethanol, $2 \times$ for $15 \mathrm{~min}, 96 \%$ ethanol, $3 \times$ for $20 \mathrm{~min}$, and $100 \%$ ethanol, $2 \times$ for $15 \mathrm{~min}$. Then $30 \mathrm{~min}$. 2:1 acetone: Epon mixture, 30 min 1:1 acetone: Epon mixture,30 min 1:2 acetone: Epon mixture, Epon pure solution overnight at $4^{\circ} \mathrm{C}$ and finally new fresh Epon solution. Consequently, they were placed in an incubator for 48 hat $65^{\circ} \mathrm{C}$ for polymerization, and were then cut with an ultra-microtome set to 50-100 $\mathrm{nm}$ section thickness. Then the sections were washed to grids made of copper or nickel. Post contrastation of the sections was determined 10 $\min 8 \%$ uranyl acetate and $5 \mathrm{~min} 0.7 \%$ lead citrate $+0.9 \%$ sodium citrate after drying for $15 \mathrm{~min}$; sections were demonstrated in a TEM, by a JEOL 2100 TEM at $80 \mathrm{KV}$ at EM Unit, Mansoura University, Egypt [61-63].

\subsection{Statistical Analysis}

All the experiments were conducted in triplicate and the results were expressed using one-way ANOVA analysis for estimating means and standard deviations ( \pm SD) [64]. The test was followed by the least significant difference (LSD) test with statistical WASP software version 2.0; LSD, at significant level $(p<0.05)$.Sample symbols (a.a): Mean nonsignificant difference; (a.b): Mean significant difference $[61,65]$.

\section{Conclusion}

The CPHs were extracted from the cowpea seeds and inhibited many pathogenic bacteria. TheAMPswere provided by treatment of CPHs by the enzyme alcalase. The AMPs were characterized using ESI-MS Spectroscopy. The MICs of the AMPs were in the range 25-150 $\mu \mathrm{g} / \mathrm{mL}$ against all the bacteria tested. The mode of action of the most active AMPs was studied by TEM studies against sensitive bacteria.

Author Contributions: Conceptualization, A.O., S.A.-S., G.E. and M.Z.S.; Data curation, N.E.-G.; Formal analysis, A.-R.A.-M.; Investigation, A.O., N.E.-G., S.A.-S., G.E., and M.Z.S.; Methodology, A.O., N.E.-G., S.A.-S. and S.A.-H.; Project administration, M.Z.S. and G.E.; Resources, A.-R.A.-M. and S.A.-S.; Software, A.O. and N.E.-G.; Writing-original draft, A.O., S.A.-S. and N.E.-G. and Writing-review and editing, A.O., M.Z.S., N.E.-G. and G.E. All authors have read and agreed to the published version of the manuscript.

Funding: Zagazig University, Zagazig. Egypt supported the experimental work. A. R. Al- Mohammadi from Department of Science, King Khalid Military Academy, Riyadh 11495, P.O. Box 22140, Saudi Arabia, were responsible for paying the publication fees.

Institutional Review Board Statement: Not applicable.

Informed Consent Statement: Not applicable.

Data Availability Statement: The data presented in this study are available in the article.

Acknowledgments: Authors are indebted to Zagazig University for practical facilities and to King Khalid Military Academy for financial support of the publication fees.

Conflicts of Interest: The authors declare that there are no conflicts of interest.

\section{References}

1. Lei, J.; Sun, L.; Huang, S.; Zhu, C.; Li, P.; He, J.; Mackey, V.; Coy, D.H.; He, Q. The antimicrobial peptides and their potential clinical applications. Am. J. Transl. Res. 2019, 11, 3919-3931.

2. Magana, M.; Pushpanathan, M.; Santos, A.L.; Leanse, L.; Fernandez, M.; Ioannidis, A.; Giulianotti, M.A.; Apidianakis, Y.; Bradfute, S.; Ferguson, A.L.; et al. The value of antimicrobial peptides in the age of resistance. Lancet Infect. Dis. 2020, 20, e216-e230. [CrossRef] 
3. Enan, G.; Abdel-Shafi, S.; Ouda, S.; Negm, S. Novel antibacterial activity of Lactococcus lactis subspecies Lactis $\mathrm{Z}_{11}$ isolated from Zabady. Int. J. Biomed. Sci. 2013, 9, 174-180.

4. Abdel-shafi, S.; Ouda, S.M.; Elbalat, I.; Enan, G. Characterization and identification of multidrug resistant bacteria from some Egyptian patients. Biotechnology 2013, 12, 65-73. [CrossRef]

5. El-Sayed, T.I.; Atef, D.; Amer, M.; Mahdy, A.; Enan, G. Molecular characterization and inhibition by natural agents of multidrug resistant Candida strains causing vaginal candidiasis. Res. J. Med. Sci. 2015, 9, 1-7.

6. Enan, G.; Osman, M.E.; Abdel-Haliem, M.E.F.; Abdel-Ghany, S.E. Advances in microbial and nuclei acids biotechnology. BioMed Res. Int. 2018, 2018, 3102374. [CrossRef]

7. Mune, M.A.M. Influence of Degree of Hydrolysis on the Functional Properties of Cowpea Protein Hydrolysates. J. Food Process. Preserv. 2015, 39, 2386-2392. [CrossRef]

8. Enan, G.; Seham, A.S.; Abdel-Halem, M.F.; Negm, S. Characterization of probiotic lactic acid bacteria to be used as starter and protective cultures for dairy fermentations. Int. J. Probiotics Prebiotics 2013, 8, 157-163.

9. Abdel-Shafi, S.; Osman, A.; Enan, G.; El-Nemer, M.; Sitohy, M. Antibacterial activity of methylated egg white proteins against pathogenic G+ and G- bacteria matching antibiotics. SpringerPlus 2016, 5, 983. [CrossRef] [PubMed]

10. Abdel-Shafi, S.; Al-Mohammadi, A.R.; Almanaa, T.N.; Moustafa, A.H.; Saad, T.M.M.; Ghonemy, A.; Anacarso, I.; Enan, G.; El-Gazzar, N. Identification and testing antidermatophyticoxaborole-6-derivative (OXBS) from Streptomyces atrovirens KM192347 isolated from soil. Antibiotics 2020, 9, 176. [CrossRef]

11. Power, O.; Nongonierma, A.B.; Jakeman, P.; FitzGerald, R.J. Food protein hydrolysates as a source of dipeptidyl peptidase IV inhibitory peptides for the management of type 2 diabetes. Proc. Nutr. Soc. 2013, 73, 34-46. [CrossRef] [PubMed]

12. El-Gazzar, N.S.; Enan, G. Advances in Phage Inspired Nanosciencebased Therapy. In Nanobioscience; Saxena, S.K., Khurana, S.P., Eds.; Springer Nature Singapore PteLtd.: Singapore, 2020.

13. El-Gazzar, N.; Almanaa, T.N.; Reda, R.M.; El Gaafary, M.; Rashwan, A.; Mahsoub, F. Assessment the using of silica nanoparticles $\left(\mathrm{SiO}_{2} \mathrm{NPs}\right)$ biosynthesized from rice husks by Trichoderma harzianum MF780864 as water lead adsorbent for immune status of Nile tilapia (Oreochromis niloticus). Saudi J. Biol. Sci. 2021. [CrossRef]

14. Askoura, M.; Saed, N.; Enan, G.; Askora, A. Characterization of polyvalent bacteriophages targeting multidrug resistant Klebsiella pneumonia with enhanced anti-biofilm activity. Appl. Biochem. Microbiol. 2021, 57, 117-126. [CrossRef]

15. Abdel-Shafi, S.; Al-Mohammadi, A.-R.; Osman, A.; Enan, G.; Abdel-Hameid, S.; Sitohy, M. Characterization and Antibacterial Activity of 7S and 11S Globulins Isolated from Cowpea Seed Protein. Molecules 2019, 24, 1082. [CrossRef]

16. Sitohy, M.Z.; Mahgoub, S.; Osman, A. In vitro and in situ antimicrobial action and mechanism of glycinin and its basic subunit. Int. J. Food Microbiol. 2012, 154, 19-29. [CrossRef] [PubMed]

17. Sitohy, M.; Osman, A. Bioactive Compounds in Soybean Proteins and Its Applications in Food Systems. In Sustainability of Agricultural Environment in Egypt: Part I; Springer: Cham, Switzerland, 2018; pp. 147-160. [CrossRef]

18. Osman, A.O.; Mahgoub, S.A.; Sitohy, M.Z. Preservative action of $11 S$ (glycinin) and 7S ( $\beta$-conglycinin) soy globulin on bovine raw milk stored either at 4 or $25^{\circ} \mathrm{C}$. J. Dairy Res. 2013, 80, 174-183. [CrossRef]

19. Abbas, E.; Osman, A.; Sitohy, M. Biochemical control of Alternaria tenuissima infecting post-harvest fig fruit by chickpea vicilin. J. Sci. Food Agric. 2020, 100, 2889-2897. [CrossRef]

20. Enan, G. Behaviour of Listeria monocytogenes LMG 10470 in Poultry Meat and its Control by the Bacteriocin Plantaricin UG 1. Int. J. Poult. Sci. 2006, 5, 355-359. [CrossRef]

21. Li, W.; Separovic, F.; O'Brien-Simpson, M.N.; Wade, D.J. Chemically modified and conjugated antimicrobial peptides against superbugs. Chem. Soc. Rev. 2021, 50, 4932-4973. [CrossRef]

22. Sitohy, M.; Osman, A. Antimicrobial activity of native and esterified legume proteins against Gram-negative and Gram-positive bacteria. Food Chem. 2010, 120, 66-73. [CrossRef]

23. Osman, A.; Mahgoub, S.; Sitohy, M. Hindering milk quality storage deterioration by mild thermization combined with methylated chickpea protein. Int. Food Res. J. 2014, 21, 693-701.

24. Osman, A.; Mahgoub, S.; El-Masry, R.; Al-Gaby, A.; Sitohy, M. Extending the technological validity of Raw Buffalo Milk at room temperature by esterified legume proteins. J. Food Process. Preserv. 2014, 38, 223-231. [CrossRef]

25. Mahgoub, S.A.; Sitohy, M.Z.; Osman, A.O. Counteracting Recontamination of Pasteurized Milk by Methylated Soybean Protein. Food Bioprocess Technol. 2011, 6, 101-109. [CrossRef]

26. Sitohy, M.Z.; Osman, A.O. Enhancing Milk Preservation with Esterified Legume Proteins. Probiotics Antimicrob. Proteins 2011, 3 , 48-56. [CrossRef] [PubMed]

27. Osman, A.; Goda, H.A.; Abdel-Hamid, M.; Badran, S.M.; Otte, J. Antibacterial peptides generated by Alcalase hydrolysis of goat whey. LWT 2016, 65, 480-486. [CrossRef]

28. Abdel-Hamid, M.; Hanan, A.; Gobba, C.; Jenssen, H.; Osman, A. Antibacterial activity of papain hydrolysed camel whey and its fractions. Int. Dairy J. 2016, 61, 91-98. [CrossRef]

29. Abdel-Hamid, M.; Romeih, E.; Saporito, P.; Osman, A.; Mateiu, R.V.; Mojsoska, B.; Jenssen, H. Camel milk whey hydrolysate inhibits growth and biofilm formation of Pseudomonas aeruginosa PAO1 and methicillin-resistant Staphylococcus aureus. Food Control 2020, 111, 107056. [CrossRef]

30. Sitohy, M.Z.; Desoky, E.-S.M.; Osman, A.; Rady, M.M. Pumpkin seed protein hydrolysate treatment alleviates salt stress effects on Phaseolus vulgaris by elevating antioxidant capacity and recovering ion homeostasis. Sci. Hortic. 2020, 271, 109495. [CrossRef] 
31. Segura Campos, M.R.; Chel Guerrero, L.A.; Betancur Ancona, D.A. Angiotensin-I converting enzyme inhibitory and antioxidant activities of peptide fractions extracted by ultrafiltration of cowpea Vigna unguiculata hydrolysates. J. Sci. Food Agric. 2010, 90, 2512-2518. [CrossRef]

32. Segura-Campos, M.R.; Chel-Guerrero, L.; Betancur-Ancona, D.A. Purification of angiotensin I-converting enzyme inhibitory peptides from a cowpea (Vigna unguiculata) enzymatic hydrolysate. Process. Biochem. 2011, 46, 864-872. [CrossRef]

33. Castañeda-Pérez, E.; Jiménez-Morales, K.; Quintal-Novelo, C.; Moo-Puc, R.; Chel-Guerrero, L.; Betancur-Ancona, D. Enzymatic protein hydrolysates and ultrafiltered peptide fractions from Cowpea Vigna unguiculata L. bean with in vitro antidiabetic potential. J. Iran. Chem. Soc. 2019, 16, 1773-1781. [CrossRef]

34. Enan, G.; Al-Mohammadi, A.-R.; Mahgoub, S.; Abdel-Shafi, S.; Askar, E.; Ghaly, M.; Taha, M.; El-Gazzar, N. Inhibition of Staphylococcus aureus LC554891 by Moringa oleifera Seed Extract either Singly or in Combination with Antibiotics. Mol. 2020, 25, 4583. [CrossRef]

35. Awika, J.M.; Duodu, K.G. Bioactive polyphenols and peptides in cowpea (Vigna unguiculata) and their health promoting properties: A review. J. Funct. Foods 2017, 38, 686-697. [CrossRef]

36. Marques, M.; Fontanari, G.; Pimenta, D.; Soares-Freitas, R.M.; Arêas, J.A.G. Proteolytic hydrolysis of cowpea proteins is able to release peptides with hypocholesterolemic activity. Food Res. Int. 2015, 77, 43-48. [CrossRef]

37. Marques, M.; Freitas, R.A.M.S.; Carlos, A.C.C.; Siguemoto, É.S.; Fontanari, G.; Arêas, J.A.G. Peptides from cowpea present antioxidant activity, inhibit cholesterol synthesis and its solubilisation into micelles. Food Chem. 2015, 168, 288-293. [CrossRef]

38. Enan, G.; Abdelshafi, S.; Ouda, S.M.; El-Balat, I. Genetic linkage of the antibiotic resistance ability in the Echerichia coli uR4 strain isolated from urine. J. Med. Sci. 2014, 3, 261-268.

39. Sukan, G.; Andrews, A.T. Application of the plastein reaction to caseins and to skim-milk powder: I. Protein hydrolysis and plastein formation. J. Dairy Res. 1982, 49, 265-278. [CrossRef]

40. Naima, N.; Karima, H.; Gabrielle, C.; Rafik, B.; Moncef, N.; Pascal, D.; Ali, B. Antibacterial peptides from barbel muscle protein hydrolysates: Activity against some pathogenic bacteria. LWTFood Sci. Technol. 2014, 55, 183-188.

41. Al-Mohammadi, A.-R.; Osman, A.; Enan, G.; Abdel-Shafi, S.; El-Nemer, M.; Sitohy, M.; Taha, M. Powerful Antibacterial Peptides from Egg Albumin Hydrolysates. Antibiotics 2020, 9, 901. [CrossRef]

42. Cheng, A.-C.; Lin, H.-L.; Shiu, Y.-L.; Tyan, Y.-C.; Liu, C.-H. Isolation and characterization of antimicrobial peptides derived from Bacillus subtilis E20-fermented soybean meal and its use for preventing Vibrio infection in shrimp aquaculture. Fish Shellfish Immunol. 2017, 67, 270-279. [CrossRef]

43. Xu, S.; Shen, Y.; Li, Y. Antioxidant Activities of Sorghum KafirinAlcalase Hydrolysates and Membrane/Gel Filtrated Fractions. Antioxidants 2019, 8, 131. [CrossRef]

44. Yust, M.D.M.; Pedroche, J.; Millán-Linares, M.D.C.; Hidalgo, J.M.A.; Millán, F. Improvement of functional properties of chickpea proteins by hydrolysis with immobilisedAlcalase. Food Chem. 2010, 122, 1212-1217. [CrossRef]

45. Cumby, N.; Zhong, Y.; Naczk, M.; Shahidi, F. Antioxidant activity and water-holding capacity of canola protein hydrolysates. Food Chem. 2008, 109, 144-148. [CrossRef] [PubMed]

46. Chalamaiah, M.; Rao, G.N.; Rao, D.G.; Jyothirmay, T. Protein hydrolysates from meriga (Cirrhinusmrigala) egg and evaluation of their functional properties. Food Chem. 2010, 120, 652-657. [CrossRef]

47. Giuliani, A.; Pirri, G.; Rinaldi, A.C. Antimicrobial Peptides: The LPS Connection. In Antimicrobial Peptides; Humana Press: Totowa, NJ, USA, 2010; pp. 137-154. [CrossRef]

48. Abdel-Shafi, S.; Osman, A.; Al-Mohammadi, A.-R.; Enan, G.; Kamal, N.; Sitohy, M. Biochemical, biological characteristics and antibacterial activity of glycoprotein extracted from the epidermal mucus of African catfish (Clariasgariepinus). Int. J. Biol. Macromol. 2019, 138, 773-780. [CrossRef] [PubMed]

49. Surówka, K.; Żmudziński, D.; Surówka, J. Enzymic modification of extruded soy protein concentrates as a method of obtaining new functional food components. Trends Food Sci. Technol. 2004, 15, 153-160. [CrossRef]

50. MuneMunea, A.M.; Minkab, R.S. Production and characterization of cowpea protein hydrolysate with optimum nitrogen solubility by enzymatic hydrolysis using pepsin. J. Sci. Food Agric. 2017, 97, 2561-2568. [CrossRef]

51. Sitohy, M.; Mahgoub, S.; Osman, A.; El-Masry, R.; Al-Gaby, A. Extent and Mode of Action of Cationic Legume Proteins against Listeria monocytogenes and Salmonella Enteritidis. Probiotics Antimicrob. Proteins 2013, 5, 195-205. [CrossRef]

52. Al-Mohammadi, A.-R.; Ibrahim, R.; Moustafa, A.; Ismaiel, A.; Zeid, A.A.; Enan, G. Chemical Constitution and Antimicrobial Activity of Kefir Fermented Beverage. Molecules 2021, 26, 2635. [CrossRef]

53. Enan, G.; El-Essawy, A.A.; Uyttendael, M.; Debevere, J. Antibacterial activity of Lactobacillus planetarium UG1 isolated from dry sausage: Characterization, production and bactericidal action of plantaricin UG1. Int. J. Food Microbiol. 1996, 30, 189-215. [CrossRef]

54. Pfalzgraff, A.; Brandenburg, K.; Weindl, G. Antimicrobial Peptides and Their Therapeutic Potential for Bacterial Skin Infections and Wounds. Front. Pharmacol. 2018, 9, 281. [CrossRef]

55. Otte, J.; Abdel-Hamid, M.; Osman, A. Comparative Assessment of Peptide Concentration in Milk Protein Hydrolysates and Fractions. Int. J. Dairy Sci. 2015, 10, 228-235. [CrossRef]

56. Adler-Nissen, J. Enzymic Hydrolysis of Food Proteins; Elsevier Applied Science Publishers LTD: Essex, UK, 1986.

57. Bauer, A.T. Antibiotic susceptibility testing by a standardized single disc method. Am. J. Clin. Pathol. 1966, 45, 149-158. [CrossRef] 
58. Abdel-Shafi, S.; Al-Mohammadi, R.; Negm, S.; Enan, G. Antibacterial activity of Lactobacillus delbreukii subspecies bulgaricus isolated from Zabady. Life Sci. J. 2014, 11, 264-270.

59. Abdel-Shafi, S.; Al-Mohammadi, A.-R.; Sitohy, M.; Mosa, B.; Ismaiel, A.; Enan, G.; Osman, A. Antimicrobial Activity and Chemical Constitution of the Crude, Phenolic-Rich Extracts of Hibiscus sabdariffa, Brassica oleracea and Beta vulgaris. Molecules 2019, 24, 4280. [CrossRef] [PubMed]

60. Morris, J.K. A formaldehyde glutaraldehyde fixative of high osmolality for use in electron microscopy. J. Cell Biol. 1965, 27, 1A-149A.

61. El-Gazzar, N.; Ismail, A.M. The potential use of Titanium, Silver and Selenium nanoparticles in controlling leaf blight of tomato caused by Alternaria alternata. Biocatal. Agric. Biotechnol. 2020, 27, 101708. [CrossRef]

62. El-Gazzar, N.; Almaary, K.H.; Ismail, A.; Polizzi, G. Influence of Funneliformismosseae enhanced with titanium dioxide nanoparticles ( $\mathrm{TiO}_{2} \mathrm{NPs}$ ) on Phaseolus vulgaris L. Under salinity stress. PLoS ONE 2020, 15, e0235355.

63. El-Bahr, S.; Elbakery, A.; El-Gazzar, N.; Amin, A.; Al-Sultan, S.; Alfattah, M.; Shousha, S.; Alhojaily, S.; Shathele, M.; Sabeq, I.; et al. Biosynthesized Iron Oxide Nanoparticles from Petroselinum crispum Leaf Extract Mitigate Lead-Acetate-Induced Anemia in Male Albino Rats: Hematological, Biochemical and Histopathological Features. Toxics 2021, 9, 123. [CrossRef] [PubMed]

64. El-Sayed, A.; Enan, G.; Al-Mohammadi, A.-R.; Moustafa, H.A.; El-Gazzar, N. Detection, Purification and Elucidation of Chemical Structure and Antiproliferative Activity of Taxol Produced by Penicillium chrysogenum. Molecules 2020, 25, 4822. [CrossRef] [PubMed]

65. Osman, A.; El-Gazzar, N.; Almanaa, T.N.; El-Hadary, A.; Sitohy, M. Lipolytic Postbiotic from Lactobacillus paracasei Manages Metabolic Syndrome in Albino Wistar Rats. Molecules 2021, 26, 472. [CrossRef] [PubMed] 